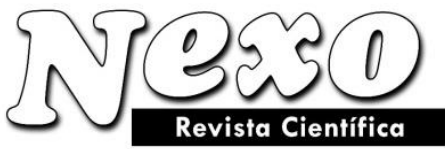

Vol. 34, No. 02, pp. 1065-1074/junio 2021
ISSN-E 1995-9516

Universidad Nacional de Ingeniería COPYRIGHT @ (UNI). TODOS LOS DERECHOS RESERVADOS http://revistas.uni.edu.ni/index.php/Nexo https://doi.org/10.5377/nexo.v34i02.11630

\title{
Critical analyzed information of International Air Transport Association
}

\author{
Información analizada crítica de la Asociación de Transporte Aéreo Internacional
}

Mohammed Almuqati

University of Jeddah, Jeddah, Saudi Arabia

mmalmuqati@uj.edu.sa

(recibido/received: 15-diciembre-2020; aceptado/accepted: 07-mayo-2021)

\begin{abstract}
The International Air Transport Association aims at representing the airline industry by enhancing awareness about the benefits of airlines to the national economies, and in this way, improving decision making regarding airline activities. Integrity is an important value if at all member airlines are expected to have trust in the organization's duty to protect their interest. The main benefit that airlines can gain in joining IATA is the ability to be adequately represented by an organization whose voice in the industry is powerful. Member airlines are also assured of financial success as IATA recommends best practices that should be implemented in order to uphold safety, environmental sustainability, and efficient processes. Ultimately, IATA's role in championing for the rights of airlines has been influential, and the improved performance in the industry is evidence that the association's efforts have been fruitful.
\end{abstract}

Keywords: Airlines, Organization, Government.

\section{RESUMEN}

La Asociación de Transporte Aéreo Internacional tiene como objetivo representar a la industria de las aerolíneas aumentando la conciencia sobre los beneficios de las aerolíneas para las economías nacionales y, de esta manera, mejorando la toma de decisiones con respecto a las actividades de las aerolíneas. La integridad es un valor importante si se espera que todas las aerolíneas miembro tengan confianza en el deber de la organización de proteger sus intereses. El principal beneficio que pueden obtener las aerolíneas al unirse a la IATA es la capacidad de estar adecuadamente representadas por una organización cuya voz en la industria es poderosa. Las aerolíneas miembro también tienen asegurado el éxito financiero, ya que la IATA recomienda las mejores prácticas que deben implementarse para mantener la seguridad, la sostenibilidad ambiental y los procesos eficientes. En última instancia, el papel de la IATA en la defensa de los derechos de las aerolíneas ha sido influyente y la mejora del desempeño en la industria es evidencia de que los esfuerzos de la asociación han sido fructíferos.

Palabras clave: Aerolíneas, Organización, Gobierno. 


\section{INTRODUCTION}

The International Air Transport Association is a trade association that represents 265 airlines located in various parts of the world. In total, 11 countries have airlines that are members of IATA. IATA's mission is to represent, lead, and serve the airline industry. IATA aims at representing the airline industry by enhancing awareness about the benefits of airlines to the national economies, and in this way, improving decision- making regarding airline activities. Representing airlines is also in line with advocating for airline interests all over the world by calling for regulation in the industry, and speaking out against unreasonable rules. IATA leads the airline industry by coming up with standards that improve airline activities. IATA also leads the industry by introducing efficient processes that reduce costs while enhancing revenue. IATA's mission of serving the industry is achieved by providing professional support which is aimed at implementing, safe, economical, and efficient processes. The organization's vision is to be the force for creating value and innovation in the aviation world, in a manner that connects and enriches the world (IATA, 2016).

IATA's values are aimed at implementing the organization's mission and vision. The first value states that the organization acts with integrity when upholding standards. Integrity is an important value if at all member airlines are expected to have trust in the organization's duty to protect their interest. IATA also thinks strategically in support of the global picture. Since the organization's members originate from various geographical regions, IATA ensures that it represents their interests in a holistic manner and in a way that will enable all the members to benefit from its actions. IATA also aims at partnering and managing with the aim of creating high performing teams. As such, the organization ensures that it forms strategic partnerships with individuals and organizations that can help it in achieving its objectives. The fourth value that is upheld by IATA is that of putting people first (IATA, 2016). Other than representing the interests of airlines, IATA, has an obligation of ensuring that all its strategies are aimed at bringing about positive effects on people (Banner, 2003).

\section{IATA HISTORY}

\subsection{Formation}

IATA was formed in April 1945 in Cuba with the aim of ensuring safe and reliable air services. During its formation, 57 airlines from eleven countries were members. The 1945 IATA's article of Association specified IATA's aims, which included the formation of a safe economical air transport with the aim of benefiting the people of the world, the provision of cooperation among air transport entities who have a direct or indirect association of international air transport service, and the cooperation with the International Civil Aviation Organization and other organizations. At the time of its formation, IATA was facing safety issues that had affected the airline industry. This led to the formulation of the standards and commended practices that outlined safety standards that were required to be followed by all the airlines. In order to ensure that the standards were enforceable by law, IATA contributed greatly to the creation of the U.S. transport law (IATA, 2016; Milde, 2016).

\subsection{Setting Price Guidelines}


Although technical and legal regulations had been implemented, IATA needed to enforce standards on the scope of operations that the airlines could engage in, the prices that could be charged to passengers and cargo, and how various airlines would settle financial obligations with each other. IATA held a Traffic Conference which was aimed at eliminating confusion regarding pricing. IATA had two aims in recommending the prices. First, it would ensure that the prices were set low so that customers would be able to afford. This way, it prevented airline travelers from being taken advantage of by airline companies. Secondly, IATA would reduce stiff competition between the airlines (IATA, 2016). Setting the airline pricing would recommend the highest and the lowest prices that the airlines were allowed to charge, and as a result, some airlines would be prevented from setting low prices that would provide a stiff competitive environment in the airline industry (Holt \& Poynor, 2016).

Providing a price mechanism for ticketing enabled airlines to avoid conflicts resulting from pricing of tickets. It also enabled the provision of inter-lining, where a customer would travel on different airlines in different countries after only paying for ticket, without the need for paying for multiple tickets to multiple airlines (Duval,2013). A number of resolutions were implemented to ensure smooth flow of operations among the airlines. One of the resolutions is known as the Multilateral Interline Traffic Agreement, and it ensures that airlines can accept each other's tickets on a give-and-take basis. The other resolution is the Passenger and Cargo Services Conference Resolution, which includes standards specifying technical specifications for tickets. The third resolution is the Passenger and Cargo Agency Agreements \& Sales Agency Rules, which specifies the relationship between IATA members and authorized intermediaries (IATA, 2016).

\subsection{Implementing Standardized Processes}

IATA's growth and development has occurred as a result of growth and development in the airline industry. In particular, the demand for airline travel has seen an increase in demand, and the airline industry has responded by using advanced technological inventions to create more efficient air crafts that are faster, use low energy, and can carry a large number of people and cargo. During the time when major changes that occurred within the airline industry, IATA was able to advise the stakeholders on issues such as sales and marketing, as well as ways of improving the processing of data in the airline industry. IATA was aware that the different methods of performing tasks that was implemented by each airline could result in confusion, and as a result, it invented standardized practices that could be employed by all the airlines. This way, uniformity was created, and IATA was able to ensure that the practiced processes were safe and efficient (IATA, 2016).

\subsection{Implementation of A Clearing House}

IATA realized that the airlines were being faced with financial issues regarding the processing of money from the authorized agents to the airlines. As a result, IATA responded by setting up a clearing house that formulated the specific functions and processes of all the parties that were involved in shifting revenue from the agents to the airlines. IATA realized that the agents lacked professional training, and it formulated an accreditation process that would teach participants the best standards in the airline industry. So far, there are approximately 81,000 agents all over the 
world, and a higher number of agents are currently undergoing training in IATA accreditation. IATA also recognized that the airlines were subjected to high taxation by the governments. This issue became more serious between 1960 and 1970, when governments increased their charges on the use of ports and on navigation services. IATA stepped in by addressing the issues with the relevant governments, and by pointing out that the governments overcharge the airlines. IATA states that the costs that should be paid for should only be for the facilities and services that have been used by the airlines. IATA also ensures that a smooth flow of cargo transit is achieved. It was successful in the implementation of the Unit Load Device (ULD), which keeps track of cargo movements. ULD also contains standards for transporting animals (IATA, 2016).

\subsection{Mtwo-Tier Division of Iata}

By 1970, air travel was no longer provided to the rich and wealthy, as it was also used by ordinary citizens. The increased use of airlines as a mode of transport was led by the introduction of bigger planes that could carry a larger number of customers. Previously, the U.S. government had granted IATA immunity from the national anti-trust law that had previously been implemented in 1946. However, the government needed to regularize the airline industry, a factor that resulted in the formation of a two-tier IATA. One part is the trade association, where the organization addressed issues related to the legal, technical, traffic, and financial services. The second-tier addresses issues concerning rates and charges for passengers and cargo. IATA sources its funding from 'marketing services that it provides to its members (IATA, 2016; Hissler, 2013). Before, funding would originate from the contributions of member airlines, but IATA's scope of activities widened, and it needed extra sources of income that would enable it to accomplish its goals and objectives. For this reason, IATA performs professional services to its member airlines as well as to other airlines that operate in the transport, travel, and tourism industries.

\section{IATA'S GOVERNANCE STRUCTURE}

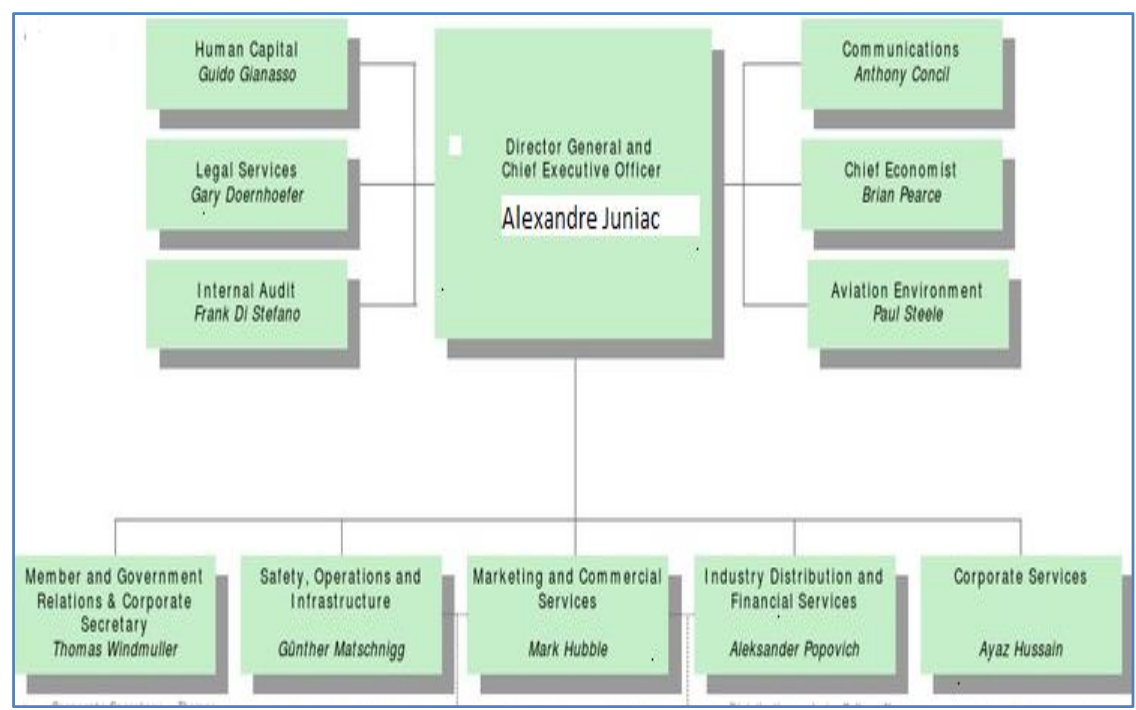

Figure1: Illustration showing IATA's governance structure 
The figure above shows IATA's governance structure. The position of the Director General and Chief Executive Officer is the topmost managerial level. The Director General and CEO directly supervises the human capital, legal services, internal audit, communications, chief economist, and aviation environment positions. The Director General and Chief CEO also has direct authority over the heads of various departments including Members and Government Relationship and Corporate Secretary, Safety Operations and Infrastructure, Marketing and Commercial Services, Industry Distribution and Financial Services, and Corporate Services. IATA maintains a hierarchical structure, where the organization's critical functions are categorized into different departments, and each head reports directly to the CEO. As a result, the CEO maintains authority over all the areas of operation. The benefit of such an organizational structure is that the CEO maintains oversight over the organization's operations, therefore ensuring that all the decisions are aligned with the organization's mission and vision. Nonetheless, a hierarchical organizational structure is ineffective when it comes to decision-making as it takes a substantial amount of time for all the decisions to be authorized by the head of the organization (IATA, 2016; Speciale, 2006).

\section{IATA'S GOVERNING BODIES}

IATA's governance is guided by the Act of Incorporation, which was assented in 1945 by the Canadian government. IATA is also guided by the Articles of Association, which contains articles that are formulated during the Annual General Meeting. The articles are subject to review and adjustments over time. The Nominating Committee also plays a vital part in carrying out IATA's objectives. More particularly, the committee recommends individuals that should be appointed to the Board of Governors. The committee reviews the competence of various individuals and selects individuals whose skills and competence satisfy the board member requirements. IATA's Board of Governors serves as the organization's government, and they are effective in exercising oversight and representing the member airlines in decision-making capacities. The Board of Governors makes important decisions regarding the running of IATA. Industry Committees also support the Board of Governors in running the organization. The Industry Committee is made up of members from six key areas comprising legal, operations, cargo, finance, industry affairs, and environment (IATA, 2016).

\section{BENEFITS OF JOINING IATA}

The main benefit that airlines can gain in joining IATA is the ability to be adequately represented by an organization whose voice in the industry is powerful. According to (Pearce,2012) members gain from internal recognition and lobbying, as the airlines achieve the status as being members of IATA. The airlines can lobby for IATA to represent their unique and collective needs to the government and suppliers. The second benefit that can be earned by being a member of IATA is that members have an opportunity of driving industry change. Collectively, the members can champion for certain changes to occur in the aviation industry by appealing to the authorities or other decision makers. Members also benefit from training, as IATA is in a position to engage in research activities that give insight into industry factors. The members are also able to get training on best practices and other industry standards that should be implemented. An overall increase in airline activities is expected after a member airline joins IATA. 
The graph below shows the industry performance for IATA's members from 2014 to 2016. Financial forecasts for a number of continents including Africa, Asia, Europe, Latin America, Middle East, and North America are provided.

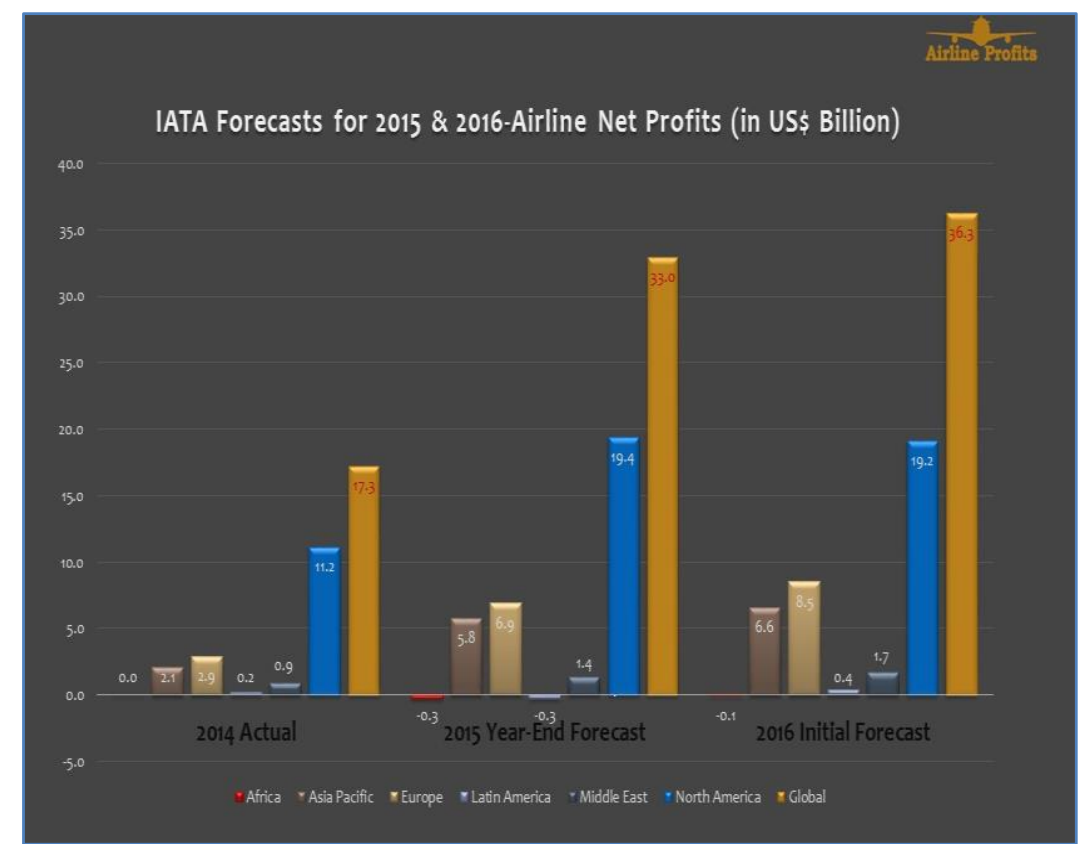

Figure 2: Graph showing performance for airlines with IATA membership

As indicated by the above graph, industry performance for 2014 was unsatisfactory, but IATA's forecasts indicate that industry performance both globally and in all the continents has improved. One of IATA's goals is to provide industry information, a factor that assists individual airlines in decision-making activities. The industries can use the market data provided by IATA to forecast their future performance and to set up strategies that will take advantage of market opportunities (Bezerra \& Gomes, 2016). The above example is one of the ways through which IATA assists member airlines in achieving success.

\section{IATA'S GOALS AND OBJECTIVES}

\subsection{Safe and Reliable Airline Services}

IATA developed six main objectives that would enable it to achieve its goals. The first objective is the promotion of safe and reliable airline services. IATA ensures that the best industry practices are implemented in all airlines so that they could be protected from all danger. Some of the dangerous activities that the organization protects its members from include the danger of technical failures that could develop from the airline activities. Other dangers include customer and cargo safety, which IATA addresses by specifying the processes that must be implemented in order to enhance safety. Thirdly, safety in the airline industry is meant to address dangers to terrorism that have been affecting the airline industries. Of late, airlines have been the source of attack by terrorism, as they have previously targeted planes and held them hostage. As a result, IATA specifies the safety guidelines that should be implemented by all the airlines to combat safety issues resulting from terrorists (IATA, 2016). 


\subsection{Financial Viability of the Airlines}

IATA also plays a role in ensuring the financial viability of the airlines. Here, The organization assists industry in boosting their levels of productivity by increasing revenues and minimizing costs. the organization works in collaboration with member airlines to implement yield management strategies that are effective in boosting revenue. More specifically, ways of ensuring that additional revenue streams are generated are implemented by IATA. One of the ways through which IATA enhances revenue is by specifying the lowest prices that can be attached on cargo and passenger tickets. As a result, price benchmarks are created, and they are effective in specifying the least amount of revenue that should be earned on cargo and passenger transportation. Secondly, IATA ensures that its members can minimize costs associated with taxation. IATA liaises with government institutions to ensure that tax obligations for airlines are kept at low levels (IATA, 2016).

\subsection{Reduction of Fees and Charges}

IATA negotiates with governments for the reduction of fees and charges that are incurred by airlines. IATA also plays a big role in lowering oil prices. Oil is a major component in the airline industry as it determines the prices that can be charged to passengers. (Duval, 2013) explains that an increase in the price of oil leads to an increase in the production costs for the airlines. In such a case, airlines either have the option of absorbing the increased costs, a factor that lowers their revenues and prevents them from accomplishing their financial goals and objectives. This in turn reduces the airline's viability, and investors could pull their resources out of the airline due to poor performance. On the other hand, the airlines could choose to increase prices for passengers and cargo, a factor that would result in customer dissatisfaction, therefore leading to a decline in sales as many customers would stop using the services of the airlines. Regardless of the options selected by the airlines, an increase in costs generally worsens their financial situation, and threatens their future. As a result, IATA has been active in calling for the reduction of oil prices by negotiating oil prices on behalf of its member airlines.

\subsection{Provision of High-Quality Products and Services}

IATA assists airlines in providing high quality products and services. The most direct way of doing this is through the formulation of best practices that should be followed by its member airlines. The best practices are determined by IATA, and they entail rules and regulations that ensure customer satisfaction. IATA therefore specifies the skills and qualifications for airline personnel holding crucial positions within the airline industry, processes for ticketing, and booking passengers and cargo, flight scheduling, among other. The second way through which IATA ensures that high quality products and services are met is through performing industry analysis which is aimed at determining customer needs. Based on the identified needs of the customer, IATA formulates the best way of satisfying customer needs. IATA's members are presented with industry reports, and they can go ahead and form strategies that are aimed at satisfying customer needs (IATA, 2016).

\subsection{Industry Support}


IATA plays a key role in addressing the unique challenges that face the airline industry. IATA represents over 260 airlines, a factor that provides the organization with bargaining power as it represents the needs of over $80 \%$ of the world's airlines. There is no other airline agency that is in a better position than IATA to represent the needs of airlines. IATA also communicates the industry position on pertinent matters. It might call for better infrastructure to be implemented by governments in order to assist the airlines in carrying out their operations. IATA also plays a big role in the formation and implementation of international laws affecting the airline industry (IATA, 2016). Similarly, IATA speaks on behalf of the industry by stating the opinions and points of view of the industry. For instance, if a law affecting the airline industry is created, IATA speaks out concerning the law, and it draws attention to either the negative or positive effects that the law might have on the airline industry.

\section{IATA'S STRATEGIES TO ENSURE THE SUCCESS OF AIRLINES}

The 21 st century has presented unique challenges that were not present before. The challenges include terrorism threats, economic turbulences, volcanic eruptions, and pandemic threats (IATA, 2016). The threats of terrorism have resulted in the creation of fear regarding air travel. As a result, many passengers have avoided airline travels after a major attack on an airline or an airport. The effects of such an attack have been the reduction in revenues associated with passenger travel. Secondly, economic turbulences have also affected the revenues earned by airlines as people's incomes are affected by economic fluctuations. For instance, during a recession or an inflation, people have less money to travel by airline or to transport cargo via airline. As such, airlines have been affected financially during such times. Volcanic eruptions in various geographic areas have crippled airline travel in such areas, and airlines have been unable to continue with their operations in such areas. There have been recent threats of pandemics such as Ebola and Zika virus, a factor that has lowered air travels as people do not want to travel in areas that have reported pandemics. Airlines are sometimes forced to cancel their flights in areas that have reported pandemics.

\subsection{Safety}

IATA has come up with strategies which ensure that the airlines can overcome the risks and threats that have been identified previously. As a result, IATA has created five initiatives that are aimed in addressing the challenges. The first initiative is the IATA Operational Safety Audit (IOSA), which is a global standard for airline safety management. IATA has taken airline safety so seriously such that it required IOSA registration as a condition for membership. IOTA requires that safety audits should be conducted in the process of carrying out training, flight operations, audit, cargo, and data collection. The aim of IOSA is to ensure that the risks associated with safety issues is mitigated by following the pre-determined rules and regulations (IATA, 2016).

\subsection{Environment Sustainability}

IATA has been effective in leading the industry to implement practices that are aligned with the conservation of the environment. Currently, IATA has a strategy of reducing the carbon emissions in the aviation industry by $50 \%$ by 2050 (IATA, 2016). For this to happen, the organization has to work together with individual airlines to design effective methods of environmental conservancy. Airlines emit carbon emissions due to burning fuel when 
transporting cargo and passengers. Some of the ways through which IATA can ensure that carbon emissions are reduced is by calling for a change in processes such that fewer flights are made. This included the introduction of bigger airlines that will carry more passengers and luggage, therefore reducing the number of trips. IATA could also call for the introduction of better engines that would burn fuel more efficiently, therefore conserving the amount of fuel used, and consequently, the amount of carbon that is emitted into the environment.

\subsection{Simplifying the Business}

IATA has aimed at ensuring the success of airlines by utilizing technology. A major achievement for the organization is the achievement of $100 \%$ e-ticketing by 2008 . The achievement of eticketing ensured that business processes associated with scheduling for flights in an efficient manner. Other initiatives that have been successfully implemented by the organization include the implementation of bar-coded passes for cargo, and e-freight services where goods that are ordered on an online platform are automatically scheduled for transportation (IATA, 2016). The simplification of business processes ensures that airlines can focus their resources to other more critical functions of the airline.

\subsection{Mar Financial Savings}

IATA has embarked on a mission to ensure that its members can get savings on costs. one way through which the organization has done that is to address the issues faced by the airlines when dealing with monopoly suppliers. Monopoly suppliers are aware that they do not have competition in the market, and their products or services play a vital role in the airline industry such that the airlines cannot do without them. The monopolies charge high prices as they are aware that the airlines have no option but to pay for their services. IATA ensures that supply chain costs are reduced. IATA negotiates prices with monopoly suppliers on behalf of the airlines. The organization's efforts have been successful, and so far, unit costs have declined by $80 \%$ since 2000 (IATA, 2016).

\section{CONCLUSION}

In summation, IATA plays a key role in representing the interests of member airlines. By joining the association, airlines are assured of enhancing their bargaining power as IATA addresses their needs to government institutions, suppliers, and other agencies. Member airlines are also assured of financial success as IATA recommends best practices that should be implemented in order to uphold safety, environmental sustainability, and efficient processes. Ultimately, IATA's role in championing for the rights of airlines has been influential, and the improved performance in the industry is evidence that the association's efforts have been fruitful.

\section{REFERENCES}

Duval, D. T. (2013). Critical issues in air transport and tourism, Tourism Geographies: An International Journal of Tourism Space, Place and Environment, 15:3.

Bezerra, G. C., \& Gomes C. F. (2016). Performance measurement in airport settings: a systematicliterature review", Benchmarking: An International Journal, Vol. 23, No.3. 
Holt, M. J., \& Poynor, P. J. (2016). Air Carrier Operations, Aviation Supplies \& Academics, Inc., 2nd Edition.

Milde, M. (2016). International Air Law and ICAO: (Essential Air and Space Law), Third Edition.

Pearce, B. (2012). The state of air transport markets and the airline industry after the great recession, Journal of Air Transport Management, Volume 21.

Speciale, R. (2006). Fundamentals of Aviation Law, 1st Edition, Kindle Edition.

Hissler, S. (2013). The Liability Law in International Air Transport: Achievements and Deficiencies.

Banner, S. (2003). Who owns the Sky, The Struggle to Control Airspace from the Wright Brothers On, Harvard University.

IATA (2016). “About Us”. Retrieved on 30-5-2021, from https://www.iata.org/en/about/. 